\title{
International technology transfer as a mechanism of activating the innovative development of a country
}

\author{
Alla Kasych ${ }^{1}$, Gulnara Medvedeva² \\ ${ }^{1}$ Kyiv National University of Technologies and Design, Kyiv, Ukraine \\ ${ }^{2}$ Brest State Techical University, Brest, Belarus
}

\begin{abstract}
The article deals with the theoretical, methodological and analytical issues of the development of international technology transfer that are becoming of increasing importance in the development of innovation processes in different countries. Identification of the content characteristics of the main forms of international technology transfer allows outlining the methodological approach for analysing their effectiveness. In accordance with the existing methodological provisions the authors suggest systematize a set of indicators for analysing the effectiveness of international trade in high-tech goods and in high-tech services, international trade in intellectual property, foreign direct investment and international migration of highly skilled workforce and students. The paper investigates the effectiveness of international technology transfer in different countries regarding the innovation processes context.
\end{abstract}

Keywords: technology, international transfer, innovation policy, technological level, gap, resource capacity, intellectual property, R\&D.

\section{Introduction}

In modern conditions, the advanced technologies, the possession of which allows the country's economy to develop more efficiently and dynamically than others, have been gaining their importance.

That is why the development of its own scientific potential, ensuring its effective use is the basis of the government innovation policies of the most developed countries of the world. Even countries with created innovative systems are trying to develop their capacity to produce new knowledge and to create new technologies. 
Nevertheless, not all modern innovative world leaders have always been in the forefront of science and technology development. Such countries as Japan, South Korea, Israel and others have been able to demonstrate high rate of innovating in activities and to build effective models of technological breakthroughs. The international technology transfer has also played an important role in these processes that is even more important for reducing the technology gap, for example, of the developing countries.

Considering the dynamics of scientific advancement in certain industries and the limited ability of even developed countries to evolve several areas of science and technology at the same time, the development of the various forms of technological cooperation takes place in the world that is advisable to consider from the standpoint of the large-scale and complex process of the international technology transfer. The gained knowledge, information and technological secrets become the basis for launching new directions of scientific development and production processes in an importing country. Further deepening of knowledge, its adaptation and improvement creates conditions for the design and development of new technology, however, provided the development of the "technological capability" of the importing country.

That is why the international technology transfer issue is relevant and needs a comprehensive research in the context of determining the content of the state policy regarding its transformation into a significant development factor, which is important for developing countries, especially to overcome the gap with technologically advanced countries.

Scientists and analysts of the international agencies are actively considering the issues of international technology transfer, since forming a comprehensive vision of the main factors and forms of the international transfer is important for many countries and enterprises. The main directions focusing of the efforts of the scientists include characteristics of the main forms, determining the content of the state policy on ITT, studying the experience of innovative leaders, etc.

Shugurova (2015) describes the international transfer of technologies (ITT) and the related processes of the protection of intellectual property rights. The issue of evaluating the technology transfer scale in the implementation of the various forms of international cooperation is presented in Roszkowskai (2013) and Mansfield (1994). The content of the government policies regarding ITT across countries group is presented directly in Hoekman, Maskus and Saggi (2005). The authors note that the content of the government policies regarding ITT varies widely in different groups of countries, and therefore needs to be substantiated. Keller (2004) has systemically studied the nature of the technology diffusion processes.

The studies devoted to summarizing the experience of developing countries occupy quite prominent place in science, the success of which is a real example for other countries focused on the innovative system formation. In this context, the works of Dahlman (2007, 2010), Xiaolan, Pietrobelli and Soete (2011) are particularly significant. Herewith, Xiaolan, Pietrobelli and Soete (2011) emphasize the importance not only of an 
attracting the technology in foreign markets, but also of creating their own indigenous ones for the developing countries.

The development prospects of the international technology transfer processes in the $21^{\text {st }}$ century are outlined by Butler and Gibson (2011).

Since the processes of international technology transfer are characterized by the complexity and dynamism, the research of their basic forms in the context of evaluating the scope and impact on innovative development are always relevant and require clarification from the standpoints of both methodology and analysis.

\section{Methods and Data}

The purpose of the article is to research the theoretical and methodological provisions of monitoring the scope of the international technology transfer in its various forms in the context of identifying the major trends of innovative development of the technological leaders in order to summarize the positive experience, the use of which will be the basis of the strategy of overcoming the technological backwardness, especially for the developing countries.

To achieve this goal it is necessary: to summarize the achievements of the leading scientists who have researched various forms of international technology transfer and the nature of its impact on innovation processes, to form methodological provisions to study the forms of the international technology transfer, to evaluate the scale and to set the main trends in the development of the international technology transfer processes; to summarize the best practices of the governments of the technological leaders on the content of the public policy in this area.

The evaluation of the scope of international technology transfer should be considered in the overall system of the research of the level of national economy innovativeness (Bruno (2013), Dahlman (2010), Vochozka (2017)), the methodology of which is more developed. Both integrated and fragmented indicators are used to evaluate the innovation levels of selected countries.

The methodology for defining the Global Innovation Index has gained the greatest distribution.

The Global Innovation Index is a composite indicator that summarizes not only the country's resource capacity for innovative activity but also the performance of this area.

There are several most common approaches including:

the Global Innovation Index calculation methodology, developed at the first in 2007 by Dutt (2016), is based on the appliance of the innovation model and reflects the complex nature of the innovation process;

the methodology of calculating the Innovation Index of the European Innovation Scoreboard, developed in 2000 by Hoddander (2011), was created to measure the effectiveness of the national researching and innovation systems in EU countries. 
The Global Innovation Index is also calculated by various international think tanks, such as WIPO, Bloomberg, and Forbes. The annual Bloomberg Innovation Index, in its seventh year, analyses dozens of criteria using seven metrics, including research and development spending, manufacturing capability and concentration of high-tech public companies.

A common feature of these techniques is the innovation process investigation through the links between two components: inputs - the resources and conditions that are key to system innovation and outputs - the totality of the results of the innovation system's function. However, the advantages of the existing methodological approaches are the grouping of indicators based on different criteria, the use of which makes it possible to identify both sectoral conditions and direct factors of innovation activity. The measurement of innovative drivers and results remains difficult from a practical point of view, so a great emphasis is placed on investigating the climate and the infrastructure for innovation.

The situation with the methodology of analysing the scope of international technology transfer is more sophisticated, since it is quite difficult to distinguish and to value all operations that contribute to the technology diffusion.

Scientific works of academics, in particular Bulter (2011), Haytera and Rooksby (2016), James (2010), Kasych (2011), Mansfield (1975), Massey (1997), Seaton (1993) propose the methodological approaches for the study of the various forms of international transfer. Accordingly, it is necessary to justify the main stages and to summarize quantitative and qualitative indicators that can directly or indirectly represent key process characteristics in order to carry out a comprehensive and multifaceted analysis of the international technology transfer.

Considering the fact that technology transfer research should be conducted in the framework of analysing the innovation processes in the economy, the following basic stages of the analysis are suggested:

- the analysis of the level of innovation of the national economy;

- the analysis of the impact of the international transfer on the economic development of the country;

- the study of indicators characterizing the forms of the international technology transfer;

- the analysis of the host country's potential for technology adsorption.

The study of its impact on the economic development of selected countries is the most important in the process of exploring the nature of the international technology transfer. This analysis allows us to evaluate the scale of the various forms of the international technology transfer and to define the causal relationships between the knowledge gained and the ability of the economic systems to ensure the technologies diffusion and their transformation into economic growth. Since international transfer of technologies is often an accompanying process in the realization of various forms of international economic interaction, basic methodological provisions should be formed and the statistical data collection should be organized for the appropriate analysis (Table 1). 
Table 1. Indicators characterizing the scale of the international technology transfer

\begin{tabular}{|l|l|}
\hline \multicolumn{1}{|c|}{ Forms ITT } & \multicolumn{1}{c|}{ Indicators } \\
\hline $\begin{array}{l}\text { International trade in high- } \\
\text { tech goods (Embodied } \\
\text { Technology Transfer) }\end{array}$ & $\begin{array}{l}\text { - share of high-tech products in the country's export / import structure; } \\
\text { - share of information and communication equipment in export / import structure; } \\
\text { structure. }\end{array}$ \\
\hline $\begin{array}{l}\text { International trade in high- } \\
\text { tech services }\end{array}$ & $\begin{array}{l}\text { - share of engineering services in the structure of export / import of services; } \\
\text { - share of consulting services in the structure of export / import of services. }\end{array}$ \\
\hline $\begin{array}{l}\text { International trade in } \\
\text { intellectual property }\end{array}$ & $\begin{array}{l}\text { - patents (purchases, sales); } \\
\text { - licenses for patents; } \\
\text { - know-how (not patented); } \\
\text { - models and designs; } \\
\text { - trademarks (including franchising); } \\
\text { - technical services; } \\
\text { - financing of industrial R\&D outside the national territory. }\end{array}$ \\
\hline Foreign direct investment & $\begin{array}{l}\text { - total volume of direct investment exports / imports and their dynamics; } \\
\text { - value and dynamics of FDI per capita per year, } \\
\text { - cost of M\&A transactions. }\end{array}$ \\
\hline $\begin{array}{l}\text { International migration of } \\
\text { highly skilled workforce and } \\
\text { students }\end{array}$ & $\begin{array}{l}\text { - share of highly qualified personnel in total labor migration from country to } \\
\text { country; } \\
\text { - share of young people who travel abroad (to travel abroad) to study; } \\
\text { - the average annual growth rate of young people leaving for study. }\end{array}$ \\
\hline
\end{tabular}

Source: Systematized by the author.

The indicators presented allow us to analyze not only the role of the selected forms of the international transfer, but also to create a comprehensive understanding of the studied processes. The results of the analysis should show, on the one hand, the importance of international technology transfer for the development of the country, and on the other hand, the role of the country (active or passive) in the international flows of the technology transfer.

\section{Results}

The acceleration of the national economy growth is increasingly based on innovation, and the innovation process is more frequently viewed as a systemic phenomenon. The wide recognition of the importance of innovation for economic and social development leads to the increase of the interest in evaluating the policies and practices of shaping innovation systems in different countries of the world. In the "knowledge economy", the winner is the one who skilfully exploits that knowledge and turns it into income. That is why the attention to innovation processes and forms of their activation is growing in an increasing number of countries and requires a comprehensive policy to promote innovation. However, innovation processes are still characterized by a high level of regional differentiation, which is clearly monitored based on the innovation development index, which should be presented in conjunction GDP per capita Fig. 1, Table 2, Appendix A. 
Figure 1. The Global Innovation Index 2018 and GDP, per person

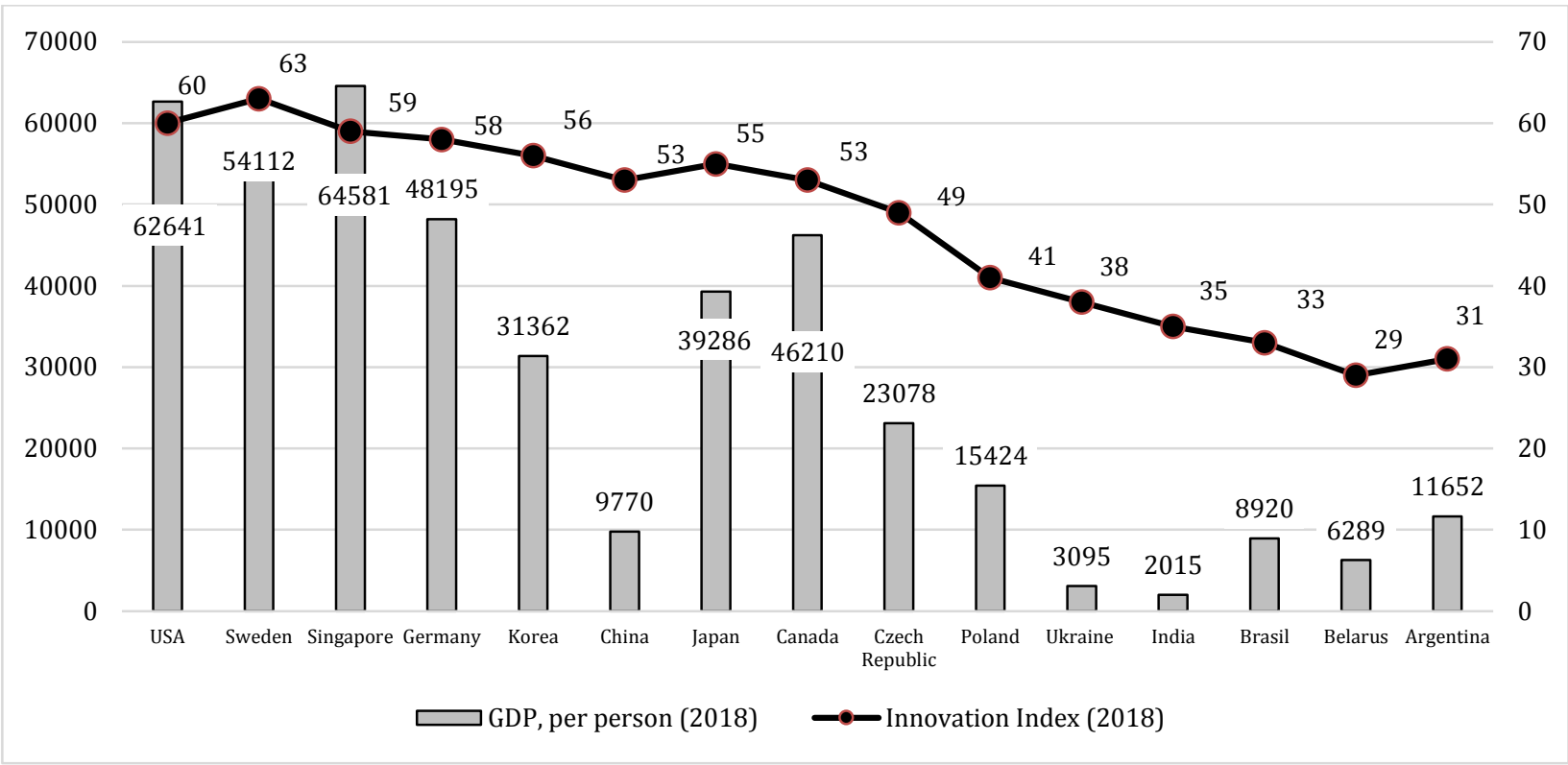

Source: Formed by the authors according to Official sites of The World Bank and Official sites of WIPO.

Table 2. Innovation leaders by income group

\begin{tabular}{|c|c|c|c|}
\hline $\begin{array}{l}\text { High income (above } \\
\$ 12,236)\end{array}$ & $\begin{array}{l}\text { Upper-middle } \\
(\$ 3,956-12,235)\end{array}$ & $\begin{array}{l}\text { Lower-middle income } \\
(\$ 1,006-3,955)\end{array}$ & $\begin{array}{l}\text { Low income (under } \\
\$ 1,005)\end{array}$ \\
\hline Switzerland ....68.40 & China ...................... & Ukraine .............38.52 & Tanzania............28.07 \\
\hline Netherlands....63.32 & Malaysia..............43.16 & Viet Nam...........37.94 & Rwanda..............26.54 \\
\hline Sweden .............63.08 & Bulgaria...............42.65 & Moldova.............37.63 & Senegal..............26.53 \\
\hline
\end{tabular}

Source: Formed by the authors according to Official sites of WIPO.

The following basic regularities were tracked based on the presented data:

\section{Innovation leaders of the world economy are mainly highly developed countries,} in particular, Switzerland, Sweden, the USA, the Netherlands, Great Britain, etc. The GDP per capita of the top ten innovators is from $\$ 50,000$ (Finland) up to $\$ 114,000$ (Luxembourg). The achieved level of the economic growth is the result of the functioning of the developed innovative systems, which provide the developed countries with the ability to create innovations independently and to determine the directions for the development of science and technology of entire industries. In spite of the fact that some EU countries are leaders in the ranking, in general the EU region is only trying to catch up with the United States. The EU at the global level is less innovative compared to Australia and Canada, South Korea and Japan, which are actively developing the capacity for innovative development. In the context of enhancing innovation development in the European Union, the EU Innovation Scoreboard is used, which allows to continuously monitor the changes in the performance and development factors of the national innovation systems of individual countries. The countries based on the research results are divided into four groups: innovators-leaders; active innovators, moderate innovators and modest innovators. 


\section{The development of economy's resource capacity is the basis of government policy in the innovative area.}

The important and illustrative indicators of resource support for innovation include such indicators as Research and development expenditure (\% of GDP), Research and development expenditure per person, Researchers in R\&D (per million people), Technicians in R\&D (per million people), which allow to compare the ability of individual countries to provide the science sector with adequate resources and to set target indicators that can be adopted in the process of the innovation strategy development.

Thus, the innovation leaders direct from 1.7 to $4.6 \%$ of GDP to the research, and the overall trend that is a characteristic of the most innovation-oriented countries is the increase in this indicator, which reflects the content of state policy regarding the GDP redistribution towards increasing the level of investment in innovation (R\&D). EU countries have defined a quantitative benchmark for innovation policy (investment in R\&D), at least $2 \%$ of GDP, since the early 1900s. Israel and South Korea direct the largest share of GDP for this purpose, i.e. over $4 \%$.

The use of the expenditure on research per capita is quite informational, since it most accurately allows estimating the real volume of science funding. Developed countries finance \$1200-1850 per capita on expenditure on research. Israel and the USA are the absolute leaders on this indicator, while the indicators of other developed countries, such as Sweden, Germany, and Japan are lower.

Thus, the basis of the high level of the innovativeness of the country's economy is the achieved overall level of the economic development (GDP) and the content of state policy to increase the level of the investment in innovation (R\&D).

\section{An increasing number of countries provide a multi-level focus on innovation development targets.}

In today's environment, the capacity of the countries to provide the economic growth on an ongoing basis depends on their ability to produce innovation. That is why the vast majority of the developing countries, despite the significant lag from leaders, focus on overcoming the gap.

Examples of several developing countries are illustrative, including South Korea and Singapore that have been able to focus their economies on innovative goals. A wellchosen strategy, initially through international technology transfer and then the development of its own high-tech production, provided for these countries not only an overcoming of a gap from the group of the developed countries, but also formed strong competitive positions in the markets of modern products and relatively stable economic growth.

Such countries as Singapore and South Korea have reached the level of the indicators of developed countries that proves the ability of the developing countries to reach the level of the developed countries according to the quantitative terms and to become an active player in the international technology market. A number of other developing and 
transformational countries are also trying to provide for the innovation orientation of investment, as evidenced by the share of these expenditures in GDP, but in absolute terms, the distance from the developed countries remains rather significant.

China is also developing in the same way. The active international technology transfer and the attempt to ensure the full development of the country's scientific potential have already given some positive results. China's GDP has actually reached $\$ 10,000$ per capita. However, in order to ensure high GDP growth in the long term, China needs a reorientation from capital-dependent development and the active involvement of technology to development, which will be ensured by the growth of overall factor productivity, that is by the ability to create modern technologies independently.

The vast majority of the developing and transformational countries are characterized by the medium level of innovation activity, as they have fragmented opportunities to develop a set of technologies. The international technology transfer is also an important factor in securing innovative economic growth for this group of countries.

The current economic development model reflects the prioritized importance of the influence of such production factor as technology, and therefore the economic growth dynamics is determined by the country's ability to provide the technological development. However, a rather limited number of countries provides the development of technology through their own efforts, and managing the international technology transfer has become the priority for others. Moreover, if the state policy for promoting international technology transfer has become clear and systematic in some countries, then the issue of international transfer is not properly assessed in other countries.

International technology transfer is the international referral process, the distribution of technology-intensive objects, which creates the conditions to overcome the technological backlog in a particular field of science and production or the economy as a whole.

There are two ways to ensure technological development of the country's economy.

1. Assuring development of technologies on its own. However, the economy has to have all the necessary resources (investments, personnel and logistics) and technological development experience for this to happen.

2. Receiving the technology from the outside by: acquiring technology in a related form (technology-intensive product or service); acquisition (receipt) of technology in "pure" form (based on licensing agreements, know-how transfer agreements, participation in scientific conferences, etc.); obtaining technology in any form by attracting FDI. The main forms of the international technology transfer are presented in fig. 1.

The technology transfer should be seen as an attempt to get ahead of the consistent process of the science and technology development in the countries with lower levels of development and which against a background of expectations of gradual evolutionary development of science may remain outside the modern processes of economic globalization for a rather long period. 
International trade in technology-intensive products plays a significant role in the technology diffusion, as it becomes a source of ideas and knowledge that allows the importing country to gradually start producing similar products and to reduce the gap to the technologically advanced countries. The import of mechanical engineering products and, first of all equipment, is especially important, since this process allows to ensure the improvement of the technological processes in other fields.

International trade in services has generally been characterized by a sufficiently high rate over the last decades, but imports of a number of services may be considered as a part of the international technology transfer processes. Thus, equipment installation, engineering, scientific and technical consulting contribute to the technological development of the developing countries. The role of the international education, which provide foreign students in developed countries with the knowledge that corresponds to the most advanced achievements of science, technology and technology, should be noted separately.

International trade in intellectual property, which involves the acquisition of licenses or other property rights for production or distribution, basic technical information or know-how, is important since it is becoming a factor in the growth of the developing countries and it allows access to modern technologies and provides manufacturers with competitive advantages.

Intellectual property, especially when it comes to high-tech, has become a highly productive intangible asset, an important result of the innovation system. This is why the leading companies in developed countries are more active in transferring technology through trading the intellectual property to countries where a stronger legal framework is more powerful to protect them.

Foreign direct investment (FDI) in some countries is a real mechanism for structural shifts, as their involvement into strategic industries generates secondary effects and can significantly effect the economic dynamics of the host country. Undoubtedly, in the process of attracting FDI to a developing country, we cannot expect the automatic development of the technological base for R\&D, since each foreign enterprise tries to protect and to maintain a monopoly on the own possession of high-tech knowledge and secrets of production. However, FDI is usually carried out by powerful transnational corporations, which, in addition to financial resources, provide for the importation of the up-to-date equipment, the transfer of experience and certain knowledge that is accompanied by the technology transfer. A variety of the organizational forms of FDI through the establishment of joint ventures, mergers and acquisitions contribute to the technology diffusion, and so objectives of state policy regarding FDI should be involved to form the conditions for attracting foreign investors who will provide not only FDI but also the technology transfer. It allows the companies from the developing countries, which attract FDI and get investor as strategic partner, entry the international distribution systems in future, and thus enables the effective entry into highly competitive markets in the most developed countries, especially into the high-tech markets. 
International movement and labour turnover in modern conditions is gaining new quantitative and qualitative characteristics and is accompanied by the unconditional transfer of technologies. Free labour migration, intensification of production internationalization processes in FDI framework, the growth of TNCs and other forms of interaction between international companies, the formation of global labour markets, the globalization of the market of educational services provide the transfer of knowledge and experience, which opens wide opportunities for the innovative development of the developing countries.

The international workforce movement will refer to the international transfer of technology in the situation when an employee returns to the country after work or study abroad and becomes the driver of technological change. This question should become the centre of the state policy in the context of providing the international technology transfer through the international labour movement.

The performance indicator of the country's innovation sector and of the international technology transfer scale is the share of high-tech exports in its total value. Using this indicator, we track the following major differences:

Innovation leader-countries have a $15-25 \%$ rate and a slight downward trend, which is generally indicative of a steady global market demand for technology-based products of this group of countries;

New industrial countries (South Korea, Singapore) and China have the highest indicator at $30-53 \%$ level of the export value, which testifies to the ability of these countries to use modern technologies in production of their own products and move to the stage of their export;

Transformation countries (Czech Republic, Poland) are also gradually increasing their high-tech exports.

Based on FDI indicators, regional features are not clearly monitored, but there are common trends:

FDI and their share of GDP are gradually increasing, however, with the exception of Singapore and Israel they have not become a significant factor in the economic development of some countries. The greatest impact is the FDI made by high-tech companies that contribute to the technological development of the production in the host country. In this context, the active involvement of such investments is of the strategic importance for the developing countries, which, through FDI-related technologies, are actively beginning to develop their own high-tech industries;

the magnitude of the net FDI inflow is volatile and indicates that the developed countries are both active exporters and importers, although a number of the developing countries are becoming active exporters. Significantly, the net investment in China has almost reached US level.

The indicators more directly reflect the International technology transfer: charges for the use of intellectual property, payments and receipts, millions and their balance (Fig. 3 ). The data presented indicate a gradual increase in the value of these transactions for 
the vast majority of countries, but with a general excess of payments over revenue. Only a few countries have a positive balance between revenues and payments from intellectual property, including the United States, the United Kingdom, Germany, and Japan. Other developed countries, developing countries, as well as transformational economies are actively using the intellectual property of other countries, making net payments abroad. The change in positions in the United Kingdom, Germany and Japan is the most significant, which have received significant net proceeds from the sale of intellectual property abroad over the last decades.

Figure 3. Net charges for the use of intellectual property, millions and their balance

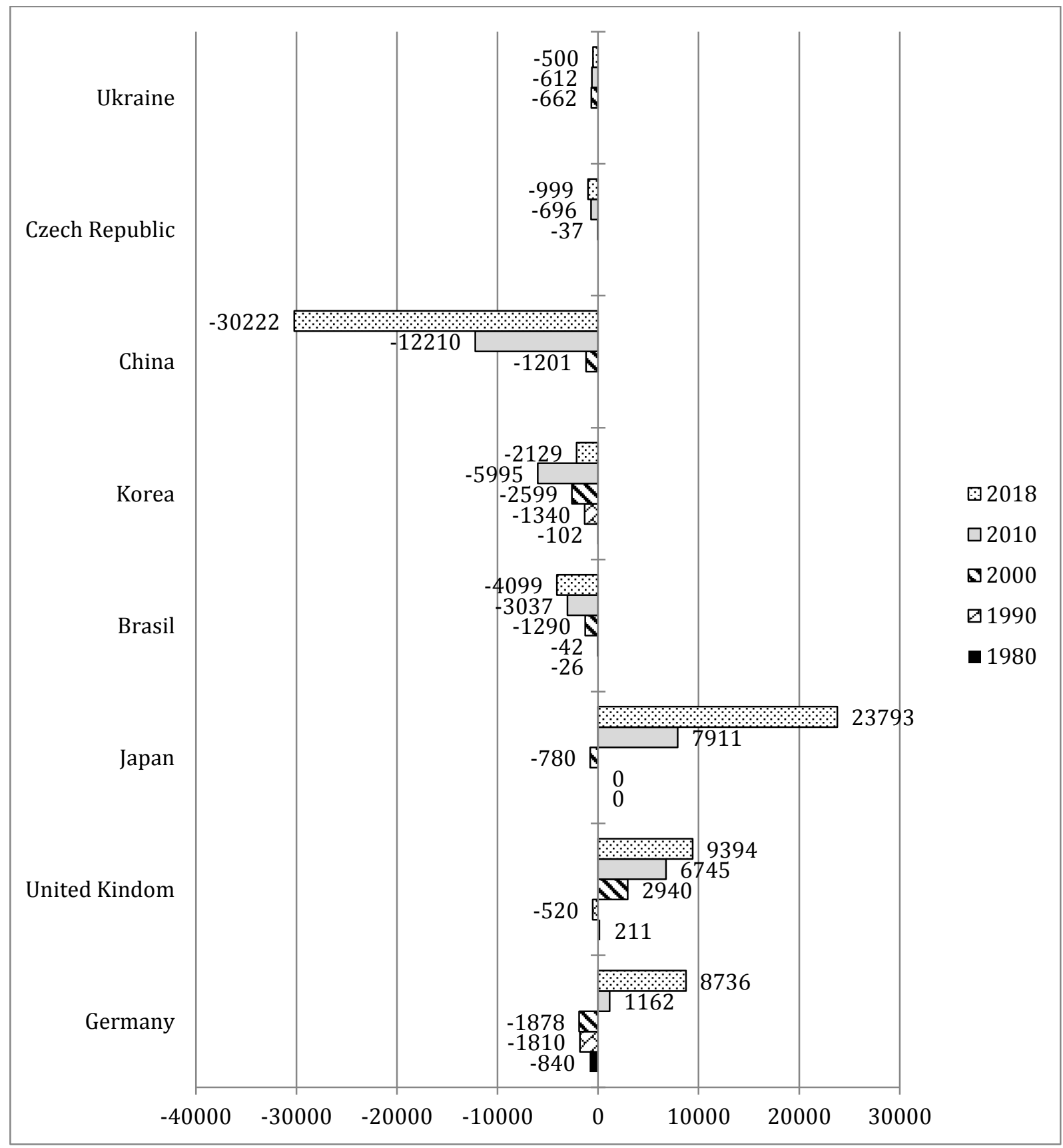

Source: Formed by the authors according to Official sites of The World Bank.

The economy of almost every country needs to import new technology in any form (development, equipment, patents, etc.), but it must learn to use these "inputs" 
effectively to transform it into its own technological capabilities. However, the use of new technologies is not a simple or automatic process. The process of the technology imports should lead to a conscious construction of the country's "technological capability", which requires the development of a new education system, infrastructure, fundamentally new characteristics of the internal market demand, etc. In fact, companies have no experience in the development of technology and must "learn to find out." In general, the processes of the impact of the technology transfer on the technological level of the growth in the developing countries can be presented in the following form (Fig. 4).

Figure 4. Scheme of the impact of the international technology transfer on the technological level of the developing countries

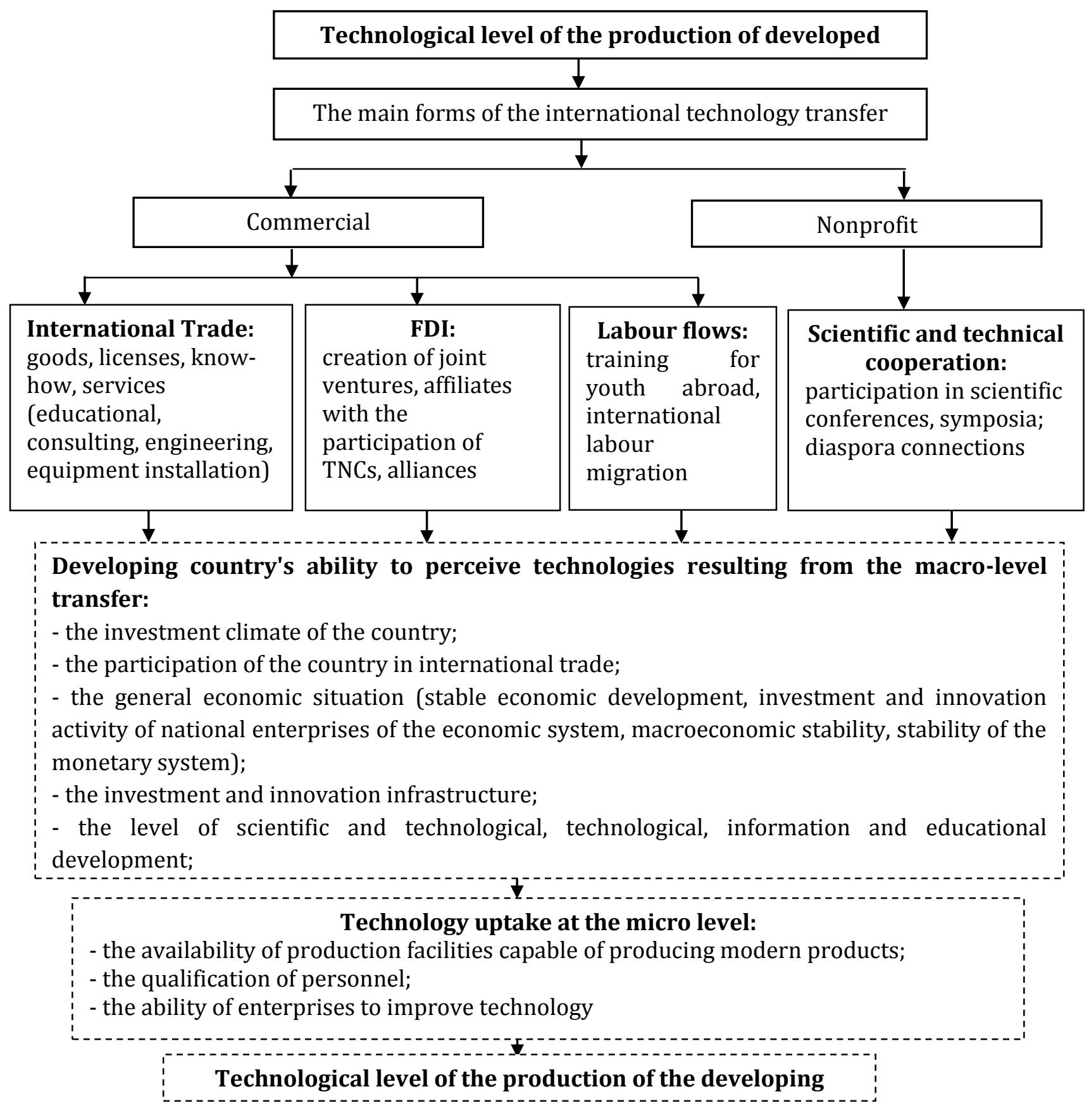


Source: Author's development.

The following should be considered as the priority task in determining the technology transfer process.

- Receiving technology from the outside can only be an initial impetus to build the potential of its development domestically.

- Existing technologies can vary significantly in potential and useful life, and therefore the ideal option is to encourage the involvement of strategically important technologies.

- The technology adoption process will be most effective if many professionals (industrial enterprises, research institutes, laboratories) are attracted to it.

- The effective use of technology and its transformation into national developments can occur only in conditions of ensuring development of all subsystems of the process of creation and use of new knowledge.

- The lack of complete information on the possible technological solution of certain production problems can lead to the waste of effort, time and resources.

Summarizing the experience of technology leaders regarding encouraging the technology development by national companies, the following basic forms of integration of science and production can be distinguished: consulting, personnel exchange, scientific parks, territorial scientific and industrial complexes, regional agglomerations, venture capital. An important function in ensuring technological development state complies with the through budget financing of $\mathrm{R} \& \mathrm{D}$, providing subsidies to the economic sectors, which contributes to the structural reform of the country's economy. If the country has not reached the level of the independent creation of new technologies, it is important to ensure the continuous access to new foreign technologies. Such access can be achieved through cooperation with TNCs, national enterprises without foreign investment, research institution, etc. One of the forms of the international technological integration of the national economy is the creation of branches, joint ventures, alliances in the process of FDI implementation. However, creating them does not solve the complex problem, but is only a partial attempt to ensure technological transfer. The main problems of participation in the alliances of domestic companies are different technological level and fundamentally different investment opportunities, and therefore it is difficult to expect partnerships.

The process of forming the technological capacity of the economic system, respectively, is advisable to consider in the context of four stages.

- Traditional production and ensuring its efficiency.

- Expanding investment opportunities increases the ability to buy and implement modern foreign technologies.

- Formation of adaptive abilities to adapt and improve imported technologies.

- Ensuring the level of R\&D, which is "keeping pace" with modern scientific and technological progress, makes it possible to generate new technologies. 
Over time, there will be real competition that promotes the dynamic development of the national market, if national technology providers emerge. Therefore, ensuring production efficiency in the today's environment requires the use of new technologies; however, a simple combination of international trade, investment and information may not ensure a positive outcome unless new opportunities are sought out. The perception of the knowledge gained by technology transfer depends on many factors and has a number of restrictions within the national economy: general investment climate in the country, macroeconomic instability, the level of development of investment and innovation infrastructure, the achieved level of scientific and technical, technological, information and educational development, etc.

The issue of improving the investment climate in the country should be considered from the standpoint of improving the legislative base for investment and innovation processes with the participation of foreign enterprises, political stabilization which is a prerequisite not only for influencing macroeconomic processes but above all for enhancing country's international investment attractiveness and contributing the rise in country's competitive position in the fight for investment resources, which are redistributed in world, the certainty of development which requires a clear justification of the content of the strategy of the long-term development of the Ukrainian economy (priorities, resources, forecasted monetary policy), simplification of the tax regulation from the standpoint of the improvement of regulatory mechanisms, raising the level of the energy security of the economic development, and upgrading the workforce qualification.

Summarizing the experience of the developing countries in the technology transfer has enabled the author to identify the main characteristics of this process and objectives for the domestic economy.

1. The technology transfer should be seen as a real and significant process for economic development, which requires considerable time and investment.

2. The current technological gap between countries necessitates investing not only in innovation but also in basic means, education, ensuring the development of all the factors the perception of knowledge acquired through transfer are dependent on.

3. Getting a certain technology because of the transfer does not solve the issue of scientific and technological development of the economic system and therefore the transfer is only a mechanism for launching internal systems for the production of technological innovations.

4. The need for rapid self-determination based on scientific and technological development determines the need to intensify the process of the technology transfer at the national level between the entities capable of producing new solutions and developments, which in turn requires the creation of information and communication networks.

5. The significant development of the country's scientific and technical potential should not be expected through the clear technology transfer even if substantial development is the object of the transfer. 


\section{Conclusion}

Therefore, the transition economies should not only promote technology transfer but also seek to develop the NIS capable of self-development. However, the experience of the developed countries is an example of the gradual evolution of the scientific progress and the process of NIS formation, which has taken place under relatively sufficient levels of financial support. From the standpoint of NIS formation in transition economies, it is more important to ensure a "technological" breakthrough in at least some industries.

Systematic shifts are needed to ensure technological shifts coordinated, since their integrity can be ensured primarily by the state. In general, there are two main strategies for government behaviour regarding the technology transfer.

- An autonomous strategy involves an active position of the state, which would promote the development of technological capabilities, increase the national ability to "keep pace" with new technologies.

- FDI dependency strategies which are divided into two types: a targeted strategy involves significantly less state intervention compared with an autonomous strategy. Free trade is being introduced but not for the whole economy, but for the export industries. The sources of the technological change remain exclusively in the hands of TNC; the passive strategy does not actually require TNC to the technology transfer. The choice of the strategy is determined by many factors but the decisive task of the developing country in terms of the technology transfer is not to remain dependent on the influx of foreign innovations but to form an internal base of opportunities in the fields of best practices.

\section{References}

BRUNO, N., IZSAK, K. and HOLLANDERS, H., 2013. New ways of measuring innovation, IUS Exploratory reports. Brussels: European Commission, 2013. [online]. Available at: http: hollanders.unumerit.nl/EIS/New\%20ways\%20of\%20measuring\%20innovation.pdf.

BUTLER, J.S. and GIBSON, D.V., 2011. Introduction: Technology transfer in global perspectives issues for the twenty-first century. In Global Perspectives on Technology Transfer and Commercialization: Building Innovative Ecosystems Edward Elgar Publishing Ltd. ISBN 9781849809771.

DAHLMAN, C., 2007. Technology, globalization, and international competitiveness: Challenges for developing countries. In: United Nations Department of Economic and Social Affairs (ed): Industrial Development in the 21st Century: Sustainable Development Perspectives. New York: United Nations: 29-83, [online]. Available at: http: http://www.un.org/esa/sustdev/publications/industrial_development/full_report.pdf.

DAHLMAN C. J., 2010, Innovation Strategies in Brazil, China and India: From Imitation to Deepening Technological Capability in the South, [in:] The Rise of Technological Power in the South, X. Fu, L. Soete (eds.), Palgrave MacMillan, London-New York. Print ISBN978-1-34931554-3.

Glossary: Technology balance of payments (TBP) [online]. Available at: http: https://ec.europa.eu/eurostat/statistics-explained/pdfscache/6345. 
DUTTA, S., LANVIN, B. and WUNSCH-VINCENT, S., 2018. The Global Innovation Index 2018: Energizing the World with Innovation. Ithaca, Fontainebleau, and Geneva. ISSN 2263-3993 [online]. Available at: https://www.wipo.int/edocs/pubdocs/en/wipo_pub_gii_2018.pdf

HAYTERA, Ch. S. and ROOKSBY, J.H., 2016. A Legal Perspective on University Technology Transfer. The Journal of Technology Transfer. 41, 270-289. ISSN: 0892-9912 [online]. Available at:

http://www.researchgate.net/publication/282448798_A_legal_perspective_on_university_techn ology_transfer.

HOEKMAN, B.M., MASKUS, K.E. and SAGGI, K., 2005. Transfer of Technology to Developing Countries: Unilateral and Multilateral Policy Options, World Development, 33(10), 1587-1602.

Hollanders, H. and Tarantola, S. 2011, Innovation Union Scoreboard 2010. Methodology Report. PROINNO Europe, Brussels.

JAMES, K.C., WEN-HONG, STACY F.L. and LEO Y.T., 2010. Evaluating Global Technology Transfer Research Performance. Department of Business Administration, China, 2010 7th International Conference on Service Systems and Service Management, IEEE, 1-6.

KASYCH, A.O., 2011. Theoretical and methodical grounds for analysis of internal sources for financing of investment activity. Actual Problems of Economics. 3(117), 243-250. ISSN 19936788.

KASYCH, A. and VOCHOZKA, M., 2017. Conceptual provisions of development of Ukrainian national innovation system. Scientific Bulletin of Polissia. 2(10), 2, 16-23. ISSN 2410-9576.

KELLER, W., 2004. International Technology Diffusion, Journal of Economic Literature. XLII, 752782.

MANSFIELD, E., 1994. Intellectual property protection, foreign direct investment, and technology transfer. The World Bank and International Finance Corporation. 38.

MANSFIELD, E., 1975. East-West technological transfer issues and problems, international technology transfer: Forms, resource requirements, and policies. American Economic Review. 65(2), 372-376. ISSN 0002-8282.

MASSEY, P.A., 1997. Knowledge Exchange Perspective of Technology Transfer. China : IEEE, 106115.Official site of The World Bank. [online]. Available at: https://data.worldbank.org/indicator.

Official sites of The World Bank. [online]. Available at: https: https://data.worldbank.org/indicator.

Official sites of WIPO. [online]. Available at: https: https://www.wipo.int/portal/en/index.html.

ROSZKOWSKAI, D., 2013. Approaches to international technology transfer measurement - an overview. [online]. Available at: http://tto.boun.edu.tr/files/1383812118_An\%20overview\%20of\%20TT\%20and\%20TT\%20M odels.pdf.

SEATON, R., 1993. The development and application of interactive models of industrial technology transfer. Tehnovation. 1(13), 45-53. ISSN 0166-4972.

SHUGUROVA, I., 2015. The International Legal Policy in the Field of Technology Transfer and the Intellectual Property Rights: Some Controversial Issues. Mediterranean Journal of Social Sciences. 6, 5, 177-185. ISSN 2039-2117.

The Global Innovation Index 2018: Energizing the World with Innovation was developed under the general direction of Francis GURRY (Director General, World Intellectual Property Organization), and the editors of the report, Soumitra DUTTA, Bruno LANVIN, and Sacha 
WUNSCH-VINCENT.

[online].

Available

at:

https://www.wipo.int/edocs/pubdocs/en/wipo_pub_gii_2018.pdf

XiAOlan, F., PIETROBelli, C. and SOETE, L., 2011. The Role of Foreign Technology and Indigenous Innovation in the Emerging Economies: Technological Change and Catching-up, World Development. 39(7), 1204-1212. ISSN 1873-5991.

\section{Contact address of the author(s):}

D. Sc. (Economics), Professor, Head of Management Department, Kyiv National University of Technologies and Design, 2 Nemyrovycha-Danchenka Street, 01011, Kyiv, Ukraine, email: kasich.alla@gmail.com 


\section{Appendix A}

Dynamics of indicators characterizing the scale of international technology transfer

\begin{tabular}{|c|c|c|c|c|c|c|c|c|c|c|c|c|c|c|c|c|c|c|c|}
\hline \multirow[t]{2}{*}{ Country } & \multirow[t]{2}{*}{$\begin{array}{c}\text { Place } \\
\text { GII } \\
2018\end{array}$} & \multicolumn{4}{|c|}{$\begin{array}{l}\text { Research and development } \\
\text { expenditure (\% of GDP) }\end{array}$} & \multicolumn{4}{|c|}{$\begin{array}{lr}\text { Research } & \text { and } \\
\text { development } & \text { expenditure } \\
\text { per person } & \end{array}$} & \multicolumn{3}{|c|}{$\begin{array}{l}\text { High-technology } \\
\text { exports } \quad(\% \quad \text { of } \\
\text { manufactured } \\
\text { exports) }\end{array}$} & \multicolumn{7}{|c|}{$\begin{array}{l}\text { Charges for the use of intellectual property, payments, } \\
\text { million dollars USA }\end{array}$} \\
\hline & & 2000 & 2010 & 2015 & 2017 & 2000 & 2010 & 2015 & 2017 & 2010 & 2015 & 2018 & 1980 & 1990 & 2000 & 2005 & 2010 & 2015 & 2018 \\
\hline \multicolumn{20}{|c|}{ Developed countries } \\
\hline USA & 6 & 2.62 & 2.74 & 2.73 & 2.80 & 955 & 1320 & 1568 & 1680 & 23.1 & 21.9 & 18.9 & 730 & 3140 & 16607 & 25577 & 32551 & 40609 & 56117 \\
\hline Germany & 9 & 2.39 & 2.71 & 2.92 & 3.04 & 652 & 1064 & 1382 & 1360 & 17.0 & 17.9 & 15.8 & 1446 & 3797 & 4414 & 7212 & 7117 & 10115 & 15631 \\
\hline UK & 4 & 1.63 & 1.67 & 1.67 & 1.67 & 456 & 653 & 742 & 670 & 23.6 & 22.7 & 22.6 & 924 & 3575 & 7139 & 10104 & 9810 & 11422 & 13364 \\
\hline Sweden & 3 & - & 3.38 & 3.26 & 3.31 & - & 1342 & 1559 & 1760 & 19.7 & 18.1 & 14.3 & 203 & 742 & 991 & 1512 & 1498 & 4173 & 4863 \\
\hline Israel & 11 & 3.93 & 3.94 & 4.28 & 4.58 & 826 & 1207 & 1534 & 1858 & 19.5 & 22.9 & 22.8 & 3 & 73 & 360 & 541 & 831 & 1062 & 1382 \\
\hline Japan & 13 & 2.91 & 3.14 & 3.28 & 3.14 & 770 & 1099 & 1335 & 1203 & 19.2 & 18.1 & 17.3 & - & - & 11007 & 14654 & 18769 & 17034 & 21726 \\
\hline \multicolumn{20}{|c|}{ Developing countries (Latin America) } \\
\hline Argentina & 80 & 0.44 & 0.56 & 0.61 & 0.53 & 34 & 58 & 84 & 77 & 7.7 & 9.3 & 5.3 & 101 & 409 & 580 & 650 & 1712 & 2178 & 2025 \\
\hline Mexico & 56 & 0.32 & 0.53 & 0.52 & 0.49 & 33 & 79 & 95 & 48 & 22.2 & 19.7 & 21.0 & 177 & 380 & 406 & 1933 & 293 & 259 & 301 \\
\hline \multicolumn{20}{|c|}{ Developing countries (NIS) } \\
\hline South Korea & 1.2 & 2.18 & 3.47 & 4.22 & 4.55 & 394 & 1048 & 1456 & 1354 & 32.0 & 31.2 & 36.3 & 125 & 1377 & 3300 & 4720 & 9183 & 10056 & 9881 \\
\hline Singapore & 5 & 1.82 & 2.01 & 2.29 & 2.22 & 434 & 950 & 1275 & 1340 & 52.3 & 52.4 & 52.7 & - & - & 5099 & 9495 & 17029 & 19400 & 15178 \\
\hline \multicolumn{20}{|c|}{ Developing countries (Asia) } \\
\hline India & 57 & 0.77 & 0.82 & 0.62 & - & 15 & 35 & 39 & - & 7.7 & 7.9 & 9.0 & 12 & 72 & 282 & 671 & 2248 & 5009 & 7906 \\
\hline China & 17 & 0.89 & 1.71 & 2.06 & 2.13 & 26 & 160 & 165 & 186 & 32.1 & 30.4 & 30.9 & - & - & 1281 & 5321 & 13040 & 22022 & 35783 \\
\hline \multicolumn{20}{|c|}{ Transitive economics } \\
\hline Poland & 39 & 0.64 & 0.72 & 1.0 & 1.04 & 68 & 152 & 125 & 144 & 7.7 & 11.0 & 10.6 & - & - & 555 & 1036 & 2248 & 2431 & 3571 \\
\hline $\begin{array}{l}\text { Czech } \\
\text { Republic }\end{array}$ & 27 & 1.11 & 1.34 & 1.93 & 1.79 & 181 & 371 & 341 & 360 & 17.9 & 17.8 & 19.6 & - & - & 81 & 503 & 945 & 1227 & 1494 \\
\hline Belarus & 86 & 0.72 & 0.67 & 0.50 & 0.59 & 9 & 41 & 30 & 34 & 3.0 & 4.4 & 3.9 & - & - & 2 & 19 & 102 & 132 & 177 \\
\hline Ukraine & 43 & 0.96 & 0.83 & 0.62 & 0.45 & 36 & 64 & 49 & 12 & 4.9 & 8.5 & 5.4 & - & - & 663 & 421 & 744 & 358 & 592 \\
\hline
\end{tabular}




\begin{tabular}{|c|c|c|c|c|c|c|c|c|c|c|c|c|c|c|c|c|c|}
\hline \multirow[t]{2}{*}{ Country } & \multicolumn{5}{|c|}{$\begin{array}{l}\text { Foreign direct investment. net } \\
\text { inflows ( } \% \text { of GDP) }\end{array}$} & \multicolumn{5}{|c|}{$\begin{array}{l}\text { Foreign direct investment. net inflows (BoP. } \\
\text { current US\$) }\end{array}$} & \multicolumn{7}{|c|}{$\begin{array}{l}\text { Charges for the use of intellectual property, receipts million } \\
\text { dollars USA }\end{array}$} \\
\hline & 1990 & 2000 & 2010 & 2015 & 2018 & 1990 & 2000 & 2010 & 2015 & 2018 & 1980 & 1990 & 2000 & 2005 & 2010 & 2015 & 2018 \\
\hline \multicolumn{18}{|c|}{ Developed countries } \\
\hline USA & 0.81 & 3.41 & 1.76 & 2.79 & 1.26 & 48490 & 350066 & 264039 & 509087 & 258390 & 7080 & 16640 & 51807 & 74448 & 107522 & 124769 & 628748 \\
\hline Canada & 0.47 & 9.20 & 1.84 & 3.86 & 2.65 & 7581 & 68303 & 29715 & 59986 & 45416 & 32 & 234 & 2324 & 2873 & 2814 & 4087 & 4840 \\
\hline Germany & 0.17 & 12.72 & 2.52 & 1.85 & 2.63 & 3004 & 247987 & 86054 & 62462 & 105278 & 606 & 1987 & 2536 & 5750 & 8279 & 16049 & 24367 \\
\hline UK & 3.07 & 9.96 & 2.72 & 1.57 & 2.08 & 33504 & 164130 & 66735 & 45333 & 58651 & 1135 & 3055 & 10079 & 15376 & 16555 & 20260 & 22758 \\
\hline Sweden & 0.77 & 8.77 & 0.13 & 2.07 & 0.84 & 1982 & 22818 & 625 & 10319 & 4632 & 89 & 563 & 1414 & 3480 & 5813 & 8828 & 7444 \\
\hline Israel & 0.26 & 6.09 & 2.99 & 3.77 & 5.62 & 151 & 8047 & 6985 & 11336 & 20789 & 12 & 62 & 496 & 574 & 849 & 1096 & 1273 \\
\hline Japan & 0.06 & 0.22 & 0.13 & 0.12 & 0.52 & 1777 & 10688 & 7441 & 5252 & 25877 & - & - & 10227 & 17655 & 26680 & 36477 & 45519 \\
\hline \multicolumn{18}{|c|}{ Developing countries (Latin America) } \\
\hline Argentina & 1.29 & 3.67 & 2.68 & 1.98 & 2.24 & 1836 & 10418 & 11333 & 11759 & 11873 & 4 & 4 & 36 & 51 & 152 & 161 & 268 \\
\hline Brazil & 0.21 & 5.03 & 3.73 & 3.35 & 4.73 & 989 & 32995 & 82390 & 60334 & 88324 & 12 & 12 & 125 & 101 & 189 & 581 & 825 \\
\hline Mexico & 0.98 & 2.59 & 1.98 & 3.16 & 3.01 & 2549 & 18382 & 20925 & 37033 & 36871 & 21 & 21 & 43 & 2 & 9 & 7 & 7 \\
\hline \multicolumn{18}{|c|}{ Developing countries (Asia) } \\
\hline India & 0.28 & 2.05 & 0.87 & 0.29 & 0.89 & 788 & 11509 & 4497 & 4104 & 14479 & 23 & 37 & 701 & 2036 & 3188 & 6553 & 7752 \\
\hline China & 15.42 & 16.15 & 22.97 & 22.65 & 22.53 & 5575 & 15515 & 55076 & 69775 & 82040 & - & - & 64 & 650 & 1933 & 8651 & 8719 \\
\hline \multicolumn{18}{|c|}{ Developing countries (Asia) } \\
\hline India & 0.07 & 0.77 & 1.64 & 2.09 & 1.55 & 236 & 3584 & 27397 & 44005 & 42117 & 0.1 & 1 & 82 & 205 & 127 & 466 & 784 \\
\hline China & 0.97 & 3.48 & 4.00 & 2.20 & 1.49 & 3487 & 42095 & 243703 & 242489 & 203492 & - & - & 80 & 157 & 830 & 1085 & 5561 \\
\hline \multicolumn{18}{|c|}{ Transitive economics } \\
\hline Poland & 0.14 & 5.43 & 3.84 & 3.15 & 2.05 & 89 & 9335 & 18395 & 15065 & 12034 & - & - & 34 & 62 & 237 & 415 & 612 \\
\hline $\begin{array}{l}\text { Czech } \\
\text { Republic }\end{array}$ & 1.61 & 8.09 & 4.90 & 0.91 & 3.46 & 654 & 4987 & 10168 & 2 & 8494 & - & - & 44 & 39 & 249 & 465 & 495 \\
\hline Belarus & 0.04 & 0.93 & 2.38 & 2.93 & 2.47 & 7 & 118 & 1393 & 11759 & 11873 & - & - & 0.9 & 3 & 8 & 22 & 65 \\
\hline Ukraine & 0.27 & 1.90 & 4.74 & 3.35 & 1.89 & 200 & 595 & 6451 & 3050 & 2476 & - & - & 1 & 22 & 132 & 86 & 92 \\
\hline
\end{tabular}

Source: Formed by the authors according to Official sites of The World Bank. 
Littera Scripta, 2019, Volume 12, Issue 2 